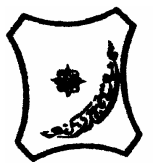

Bayero Journal of Pure and Applied Sciences, 6(1): 7- 11

Received: December 2012

Accepted: May 2013

ISSN $2006-6996$

\title{
BREAKFAST CONSUMPTION PATTERN OF SOME AHAMDU BELLO UNIVERSITY STUDENTS AND NUTRIENT COMPOSITION OF COMMONLY CONSUMED BREAKFAST FOODS
}

\author{
*Anigo, K.M., Owolabi, O. A., Sule, M. and Oluloto, A.O. \\ Department of Biochemistry, Ahmadu Bello University, Zaria. \\ *Correspondence author: mkanigo@yahoo.com
}

\begin{abstract}
This study was carried out to evaluate breakfast consumption pattern of university students and determine nutrient composition of some commonly consumed breakfast foods. Seventy five (75) students took part in the study, using semi-structured questionnaires to obtain information on breakfast consumption pattern and 24-hour dietary recall to document dietary intake. Standard methods were used to determine weight and height from which their body mass index was calculated. Proximate and mineral compositions of some breakfast foods were determined using standard methods. Results obtained showed $85.3 \%$ of respondents eat breakfast while $14.7 \%$ skipped breakfast. Breakfast contribution to total calorific consumption of breakfast eaters was $2651.86 \mathrm{kcal}$ compared to $1981.00 \mathrm{kcal}$ for breakfast skippers. Both groups showed lower intake of some vitamins and micronutrients when compared to RDA. Nutrient content of commonly consumed breakfast foods revealed moimoi and bean cake had $16.44 \pm 0.70 \mathrm{~g} / 100 \mathrm{~g}$ and $22.19 \pm 0.08 \mathrm{~g} / 100 \mathrm{~g}$ crude protein respectively, while fried yam had high amount of carbohydrate 41.12 $\pm 2.12 \mathrm{~g} / 100 \mathrm{~g}$. Millet pap recorded higher content of magnesium $(18.55 \pm 0.03 \mathrm{mg} / 100 \mathrm{~g})$, calcium (28.73 $\pm 0.52 \mathrm{mg} / 100 \mathrm{~g})$, copper (26.33 $\pm 0.08 \mathrm{mg} / 100 \mathrm{~g})$ and Chromium $(1.09 \pm 0.05 \mathrm{mg} / 100 \mathrm{~g})$. A healthful breakfast food choices by students may be an important strategy for improving the nutritional quality of their dietary intake.
\end{abstract}

Keywords; Students, Breakfast, Food, Nutrient composition

\section{INTRODUCTION}

A large body of research supports breakfast's key role in helping adults and children meet nutrition recommendations (IFIC, 2012). Many studies have shown associations between hunger, poor dietary intake, stunting, underweight, and poor school performance after controlling for socioeconomic conditions (Grantham-McGregor, 2005). Breakfast is also widely promoted to improve cognitive function and academic performance, leading to the provision of breakfast initiatives by public health bodies (Hoyland et al., 2009). Numerous observational studies show that eating breakfast has a beneficial effect on academic and achievement test scores (Boey et al., 2003), grades (Kleinman et al., 2002; Kim et al., 2003), school attendance (Kleinman et al., 2002), and tardiness rates (Murphy et al., 1998).

Regular breakfast consumption is associated with higher intake of several vitamins and minerals, which boosts the likelihood of meeting recommendations for these nutrients (Rampersaud et al., 2005; Kerver et al., 2006). There are indications in some countries that breakfast consumption among adults is declining (Akinyele et al., 1997) especially among young adults and children. A lack of time available to eat breakfast before school may be a factor in breakfast omission, since it was discovered that children were more likely to eat a substantial breakfast during holidays, than on school days (Ortega et al., 1998). Reports on breakfast omission in adults vary depending on the country under consideration. This study was to evaluate the impact of breakfast consumption patterns on the nutritional adequacy of diets and determine nutrient composition of commonly consumed breakfast foods by some Ahmadu Bello University students.

\section{MATERIALS AND METHODS}

Subjects

Subjects that participated in this study are students of Ahmadu Bello University, Zaria-Nigeria. They were enlightened on the significance of the study and need for honest and fair response in completing the questionnaires and assurance of confidentiality on information provided.

Methods

Data on breakfast consumption pattern was collected using semi-structured questionnaires. Samples of commonly consumed breakfast foods were collected for nutrient analyses. Dietary intake was assessed by 24-hours dietary recall. Nutrient contribution of breakfast was calculated using food composition table (Akinyele et al., 1997). For anthropometric measurements; weight was measured using UNICEF digital type scale and measured to the nearest $0.1 \mathrm{~kg}$ while standing height was measured to the nearest $0.5 \mathrm{~cm}$ using a standiometer fitted with a detachable head-board. Sample analyses and preparation of standard solutions were done according to the procedures published by AOAC (1990). Proximate composition of food samples were determined as described by AOAC (1990). 
Total carbohydrate was determined by difference. Mineral element concentrations were determined using Zeeman Polarized Atomic Absorption Spectrophotometer (Hitachi, model 180-80). Statistical Analysis: SPSS version 16 was used for data collation and to calculate Mean and standard deviation.

\section{RESULTS}

Characteristics of subjects are shown in Table 1 which reveals that $54.7 \%$ of subjects were females and $45.3 \%$ were males. Most of the respondents (73.2\%) were between ages of 20 to 24 years. Anthropometric characteristics as shown in Table 2 indicate mean weight of the subjects was $63.88 \pm 7.03 \mathrm{Kg}$ (males $71.02 \pm 1.34 \mathrm{Kg}$ females $57.74 \pm 1.51 \mathrm{Kg}$ ), mean height was $1.71 \pm 0.07 \mathrm{~m}$ (males $1.77 \pm 0.013 \mathrm{~m}$; females $1.65 \pm 0.01 \mathrm{~m})$. Mean Body Mass Index (BMI) was higher in males than in females. Result of breakfast eating pattern (Table 3 ) revealed $85.3 \%$ of the respondents ate breakfast while $14.6 \%$ skipped breakfast. Highest proportion of respondents (27.7\%) ate breakfast to prevent head and stomach aches while $23.1 \%$ was a habit (Table 4 ). Table 5 showed equal proportions $(27.3 \%)$ of respondents that skip breakfast was to lose weight and time constraint. Frequency at which breakfast is eaten shows that $22.2 \%$ of respondents ate breakfast everyday while timing revealed that $54.8 \%$ ate before school and $4.8 \%$ reported they ate before a test. Also $82.4 \%$ of eaters prepare breakfast in the hostel while $7.6 \%$ patronized open vendors. General perception of subjects with respect to hunger shows that $76.9 \%$ of those that skip breakfast experience hunger on reaching school as against $24.2 \%$ breakfast eaters.

Presented in Table 6 is the nutrient intake of respondents. Breakfast eaters had mean energy intake of $2651.86 \mathrm{kcal}$ and protein $65.82 \mathrm{~g}$ while breakfast skippers had $1981 \mathrm{kcal}$ and $48.83 \mathrm{~g}$ for energy and protein respectively. Both groups of respondents showed insufficient intake of iron, calcium, vitamin A, thiamine and ascorbic acid with that for breakfast skippers lower than breakfast eaters. Table 7 shows the contribution of breakfast to nutrient intake of subjects which revealed that the mean energy intake was $2651.86 \mathrm{kcal}$ with breakfast contributing 677.01 kcal $(25.53 \%)$ to the total energy intake. Mean protein intake was $65.82 \mathrm{~g}$ with breakfast contributing $26.22 \mathrm{~g}$ (39.84\%) while breakfast contribution to total carbohydrate was $24.11 \%$. Result of proximate composition of some locally consumed breakfast foods are shown in Table 8. Moi moi and bean cake (kosai) recorded highest level of protein concentration both of which are of leguminous plant source. Table 9 reveals results of some mineral element in some commonly consumed breakfast foods. Result indicated that millet pap had the highest content of magnesium (18.55$\pm 0.03 \mathrm{~g} / 100 \mathrm{~g})$, calcium $(28.73 \pm 0.52 \mathrm{~g} / 100 \mathrm{~g})$, copper $(26.33+0.08 \mathrm{~g} / 100 \mathrm{~g})$ and Chromium $(1.09 \pm 0.05 \mathrm{~g} / 100 \mathrm{~g})$.

Table 1: Characteristic of Respondents

\begin{tabular}{lcc}
\hline Characteristic & Frequency & Percentage \\
\hline Distribution of sex & 34 & 45.3 \\
Male & 41 & 54.7 \\
Female & & \\
Distribution of age & 14 & 18.6 \\
$<20$ & 54 & 72.0 \\
$20-24$ & 7 & 9.3 \\
$>24$ & & \\
Sponsor & 73 & 97.2 \\
Private & 2 & 2.8 \\
Scholarship & \multicolumn{2}{|c}{} \\
Monthly stipend & 8 & 13.3 \\
$<$ N3000 & 43 & 71.6 \\
N3000- 5000 & 9 & 15.0 \\
$>$ N5000 & &
\end{tabular}

Table 2: BMI Distribution of Subjects According to Sex

\begin{tabular}{llll} 
& Male & Female & All subject \\
& $\mathbf{n = 3 4}$ & $\mathbf{n = 4 1}$ & $\mathbf{n = 7 5}$ \\
Weight & $71.10 \pm 1.35$ & $58.74 \pm 1.51$ & $68.88 \pm 7.04$ \\
Height & $1.77 \pm 0.01$ & $1.65 \pm 0.01$ & $1.712 \pm 0.07$ \\
BMI & $22.46 \pm 0.30$ & $21.22 \pm 0.43$ & $21.66 \pm 2.00$ \\
\hline
\end{tabular}

Values are mean \pm standard deviation.

Table 3. Breakfast Eating Pattern of Respondents

\begin{tabular}{lcc}
\hline Respondents & Frequency & \% \\
Breakfast Eaters & 64 & 85.3 \\
Breakfast Skippers & 11 & 14.7 \\
Total & 75 & 100.0 \\
\hline
\end{tabular}


Table 4: Reason for eating breakfast

\begin{tabular}{lcc}
\hline Reasons & Frequency & Percentage \\
\hline Most important meal & 13 & 20.0 \\
To prevent head and stomach & 18 & 27.7 \\
aches & & \\
To gain weight & 12 & 18.5 \\
Habit & 15 & 23.1 \\
Not specific & 6 & 9.3 \\
\hline
\end{tabular}

Table 5: Reason for skipping breakfast

\begin{tabular}{lcc}
\hline Reasons & Frequency & Percentage \\
\hline Wake up late & 2 & 18.2 \\
To loss weight & 3 & 27.3 \\
No time to prepare breakfast & 3 & 27.3 \\
Not hungry & 1 & 9.1 \\
No food to eat & 2 & 18.2 \\
\hline
\end{tabular}

Table 6: Comparison of nutrient intake of breakfast eaters and skippers

\begin{tabular}{lrrr}
\hline Nutrients & RDA & Breakfast Eaters Intake & Breakfast Skippers Intake \\
\hline Energy (kcal) & 2169.00 & 2651.86 & 1981.00 \\
Protein (g) & 54.00 & 65.82 & 48.80 \\
Calcium (mg) & 500.00 & 203.18 & 315.40 \\
Iron (mg) & 12.00 & 10.25 & 6.31 \\
Vitamin A (mg) & 750.00 & 315.60 & 210.72 \\
Thiamine (mg) & 1.200 & 0.58 & 0.91 \\
Ascorbic acid (mg) & 30.00 & 30.41 & 22.00 \\
Folic acid (mg) & 2.00 & 1.33 & 2.74 \\
\hline
\end{tabular}

Table 7: Contribution of breakfast to nutrient intake

\begin{tabular}{lccc}
\hline Nutrients & Intake & $\begin{array}{c}\text { Supplied by } \\
\text { breakfast }\end{array}$ & $\begin{array}{c}\text { Breakfast as } \\
\text { percentage intake }\end{array}$ \\
\hline Energy (kcal) & 2651.86 & 677.01 & 25.53 \\
Total Protein $(\mathrm{g})$ & 65.82 & 26.22 & 39.84 \\
Total lipids $(\mathrm{g})$ & 79.62 & 18.77 & 23.57 \\
Carbohydrate $(\mathrm{g})$ & 418.00 & 100.80 & 24.11 \\
\hline
\end{tabular}

Table 8: Proximate Composition of Some Locally Consumed Breakfast foods by Respondents (\%)

\begin{tabular}{lllllll}
\hline & \multicolumn{1}{c}{ Moisture } & \multicolumn{1}{c}{ Ash } & \multicolumn{1}{c}{ Crude Fat } & Crude Fibre & Crude Protein & Carbohydrate \\
\hline Fried yam & $38.39 \pm 3.10$ & $2.12 \pm 0.1$ & $15.95 \pm 0.13$ & $1.53 \pm 0.16$ & $2.30 \pm 0.14$ & $41.12 \pm 2.12$ \\
Millet pap & $85.01 \pm 3.60$ & $0.513 \pm 0.05$ & $0.23 \pm 0.02$ & $0.03 \pm 0.01$ & $2.50 \pm 0.28$ & $11.74 \pm 1.30$ \\
Moi moi & $55.58 \pm 2.40$ & $1.92 \pm 0.13$ & $17.474 \pm 1.70$ & $0.12 \pm 0.03$ & $16.44 \pm 0.72$ & $7.91 \pm 0.78$ \\
Bean cake ('kosai') & $44.08 \pm 2.70$ & $2.173 \pm 0.08$ & $22.05 \pm 2.20$ & $0.64 \pm 0.08$ & $22.19 \pm 0.80$ & $9.8 \pm 77$ \\
\hline
\end{tabular}

Values are mean \pm standard deviation of triplicate determinations

Table 9: Concentration Mineral Element of Some Locally Consumed Breakfast Food by Respondents (mg/100g)

\begin{tabular}{lcccccccc}
\hline Food & $\mathbf{F e}$ & $\mathbf{N a}$ & $\mathbf{M g}$ & $\mathbf{C a}$ & $\mathbf{K}$ & $\mathbf{C u}$ & $\mathbf{C r}$ & $\mathbf{Z n}$ \\
\hline Fried yam & $4.03 \pm$ & $17.02 \pm$ & $8.85 \pm$ & $9.03 \pm$ & $14.39 \pm$ & $24.46 \pm$ & $0.65 \pm$ & $4.84 \pm$ \\
& 0.03 & 0.14 & 0.50 & 0.02 & 0.02 & 0.30 & 0.05 & 0.03 \\
Millet pap & $4.17 \pm$ & $15.42 \pm$ & $18.55 \pm$ & $28.73 \pm$ & $11.53 \pm$ & $26.33 \pm$ & $1.09 \pm$ & $4.98 \pm$ \\
& 0.05 & 0.17 & 0.03 & 0.52 & 0.07 & 0.077 & 0.05 & 0.67 \\
Moimoi & $4.20 \pm$ & $5.91 \pm$ & $11.62 \pm$ & $16.50 \pm$ & $9.64 \pm$ & $22.57 \pm$ & $0.82 \pm$ & $4.76 \pm$ \\
& 0.26 & 0.06 & 0.32 & 0.40 & 0.02 & 0.12 & 0.01 & 0.26 \\
Bean cake ('kosai') & $3.67 \pm$ & $7.44 \pm$ & $9.16 \pm$ & $8.55 \pm$ & $13.04 \pm$ & $23.48 \pm$ & $0.90 \pm$ & $5.20 \pm$ \\
& 0.05 & 0.03 & 0.67 & 0.02 & 0.14 & 0.64 & 0.03 & 0.17 \\
\hline
\end{tabular}

Values are mean \pm standard deviation of triplicate determinations

\section{DISCUSSION}

Breakfast consumption has been identified as an important factor in nutritional well-being and plays an important role in helping adults meet nutrition recommendations (Timlin and Pereira, 2007). BMI is an indicator of degree of fatness of respondents
(WHO, 2000) and BMI above 27.8 and $27.3 \mathrm{~kg} / \mathrm{m}^{2}$ for men and women, respectively, may increase mortality and reports (Brown et al., 2000; Meisler and St Jeor, 1996) have mentioned a BMI below $25 \mathrm{~kg} / \mathrm{m}^{2}$ as a suitable index for women. 
The BMI obtained in this study for both male and female students was within the suitable index. However, a significantly low BMI in women did not only indicates disorder and malnutrition, but also leads to osteopenia and osteoporosis and increases the risk of prematurity and giving birth to under-weight children (Villena-Heinsen, et al., 1998). Several observational studies suggest that eating breakfast is associated with lower BMI, and skipping breakfast is associated with higher BMI (IFIC, 2012).

As revealed in this study high proportion of the respondents ate breakfast. Breakfast consumption makes an important nutritional contribution to total daily intake of students (Nicklas et al., 2000). Higher nutrient intake by breakfast eaters compared to breakfast skippers was observed in this study with mean energy intake for breakfast eaters higher than 485 kcal reported (Nicklas et al., (1998). Inadequate breakfast contributes to poor school performance with the dietary inadequacies rarely compensated for in other meals of the day (Nicklas et al., 1998). Breakfast eaters have higher daily intakes of micronutrients and are more likely to meet nutrient intake recommendations compared with individuals who don't eat breakfast, particularly for Vitamin A

\section{REFERENCES}

Akinyele, I.O., Aminu, F.T. and Oguntona, E.B (1997). Computerised data base on ethiocultural food commonly eaten in Nigeria. Am. J. Clin. Nutri. 65(5): 1331s- 1335s.

AOAC (1990). Official methods of analysis 14th Edition. Association of Official Analytical Chemist. Washington DC, USA.

Boey C.C., Omar, A, and Arul-Phillips, J. (2003). Correlation among academic performance, recurrent abdominal pain and other factors in year-6 urban primary-school children in Malaysia. J. Paediatr. Child Health.39:352-357.

Brown WJ, Mishra G, Kenardy J, Dobson A. Relationships between body mass index and well-being in young Australian women. Int $J$ Obes Relat Metab Disord. 24(10):1360-8

DRI (2001). Dietary Reference Intakes for Vitamin A, Vitamin K, Arsenic, Boron, Chromium, Copper, Iodine, Iron,Manganese, Molybdenum, Nickel, Silicon, Vanadium, and Zinc (2001) DRI reports, www.nap.edu

Grantham-McGregor, S. (2005). Can the provision of breakfast benefit school performance? Food Nutr Bull. 26(2 Suppl 2):S144-S158.

Hoyland, A., Dye, L. and Lawton, C.L. (2009). A systematic review of the effect of breakfast on the cognitive performance of children and adolescents. Nutr. Res. Rev. 22(2):220-43.

IFIC (2012). International Food Information Foundation. Breakfast and Health. IFIC Review. http://ific.org Accessed September 8, 2012.

Kerver, J.M., Yang, E.J., Obayashi, S., Bianchi, L. and Song, W.O. (2006). Meal and snack patterns are associated with dietary intake of energy and nutrients in U.S. adults. $J \mathrm{Am}$ Diet Assoc.106:46-53.
Calcium, Vitamin C, Zinc, Iron and Riboflavin (Rampersaud et al., 2005; Kerver et al., 2006). This study showed that breakfast makes more contribution to some micronutrient consumption like Iron, Vitamin $A$ and Ascorbic acid. Based on dietary recall (Table 6) intake of Iron, vitamin A and Ascorbic acid by breakfast eaters was higher than breakfast eaters. The mineral composition in some of the commonly eaten breakfast foods analysed in this study can make significant contribute to RDA requirement. Iron and Zinc concentrations in the breakfast foods analysed can contribute up to $50 \%$ to RDA requirement of $8 \mathrm{mg} / \mathrm{d}$ and $8-11 \mathrm{mg} / \mathrm{d}$ (DRI, 2001) respectively. Appreciable amount of copper could also be made to the RDA of $900 \mathrm{ug} / \mathrm{d}$ (DRI, 2001).

\section{CONCLUSION}

Results of this study indicate consumption of breakfast foods contributed about one third of total daily energy and protein requirement of respondents. There is need to encourage consumption of breakfast by students, along with selection of more healthful breakfast food choices that are culturally appropriate which may be an important strategy for improving the nutritional quality of their dietary intake.

Kim, H.Y., Frongillo, E.A., Han, S.S., Oh, S.Y., Kim, W.K., Jang, Y.A., Won, H.S., Lee, H.S. and Kim, S.H (2003). Academic performance of Korean children is associated with dietary behaviours and physical status. Asia Pac. J. Clin. Nutr. 2003;12:186-192.

Kleinman, R.E., Hall, S., Green, H., Korzec-Ramirez, D., Patton, K, Pagano, M.E. and Murphy, J.M (2002). Diet, breakfast, and academic performance in children. Ann. Nutr. Metab. 46(suppl 1):24-30.

Meisler JG, St Jeor S. Summary and recommendations from the American Health Foundation's Expert Panel on Healthy Weight. Am J Clin Nutr. 1996;63(3 Suppl):474S-7S.

Murphy, J.M., Pagano, M.E., Nachmani, J., Sperling, P., Kane, S. and Kleinman, R.E. (1998). The relationship of school breakfast to psychosocial and academic functioning: cross-sectional and longitudinal observations in an inner-city school sample. Arch. Pediatr. Adolesc. Med. 152:899907.

Nicklas, T.A., Myers, L., Reger, C., Beech, B. and Berenson, G.S. (1998). Impact of breakfast consumption on nutritional adequacy of the diets of young adults in Bogalusa, Louisiana: ethnic and gender contrasts. J. Am. Diet. Assoc. 98:1432-1438.

Nicklas TA, Reger C, Myers L, O'Neil C. (2000). Breakfast consumption with and without vitamin-mineral supplement use favorably impacts daily nutrient intake of ninth-grade students. J Adolesc Health. 27(5):314-21.

Ortega, R.M.. Requejo, A.M., Lopez Bonilla, M.D. and Rivas, T. (1998). Difference in the breakfast habits of over weigh/obsess and normal weight school children. Internal J. Vit. Nutr. Res. 68: $125-132$. 
Rampersaud, G.C., Pereira, M.A., Girard, B.L., Adams, J. and Metzl, J.D. (2005). Breakfast habits, nutritional status, body weight, and academic performance in children and adolescents. $J$. Am. Diet. Assoc. 105:743-760.

Timlin, M.T. and Pereira, M.A. (2007). Breakfast frequency and quality in the etiology of adult obesity and chronic diseases. Nutr. Rev. 65:268-281.
Villena-Heinsen C, Luxner K, Friedrich M, Quijano F, Schmidt W. (1998). Pregnancy and labor in underweight pregnant patients. $Z$ Geburtshilfe Neonatol.202(3):115-20.

WHO (2000). Obesity: preventing and managing the global epidemic. Report of a WHO Consultation. WHO Technical report Series 894. Geneva: World Health organization. 